$1-1-1998$

\title{
Effect of Transatlantic Transport on Reproduction of Agouti and Nonagouti Deer Mice, Peromyscus maniculatus
}

Virginia Hayssen

Smith College, vhayssen@smith.edu

Follow this and additional works at: https://scholarworks.smith.edu/bio_facpubs

Part of the Biology Commons

\section{Recommended Citation}

Hayssen, Virginia, "Effect of Transatlantic Transport on Reproduction of Agouti and Nonagouti Deer Mice, Peromyscus maniculatus" (1998). Biological Sciences: Faculty Publications, Smith College, Northampton, MA.

https://scholarworks.smith.edu/bio_facpubs/73

This Article has been accepted for inclusion in Biological Sciences: Faculty Publications by an authorized administrator of Smith ScholarWorks. For more information, please contact scholarworks@smith.edu 


\section{Effect of transatlantic transport on reproduction of agouti and nonagouti deer mice, Peromyscus maniculatus}

\section{Hayssen}

Department of Physiology \& Environmental Sciences, University of Nottingham, Sutton Bonington, Leics LE12 5RD, UK and Department of Biology, Smith College, Northampton, MA, USA

\section{Summary}

In conjunction with establishing colonies of deer mice in the UK, effects of transportation on reproduction in agouti (A) and nonagouti (a) deer mice were assessed. Adults were shipped via ground courier and air freight from N orthampton, Massachusetts, USA to Sutton Bonington, Leicestershire, England in February and June. Deer mice were paired upon arrival in Sutton Bonington, whereas matched controls were paired in the original colonies at shipping. To assess reproduction, the following variables were monitored for 110 days for all 96 pairs: number of pairs producing litters, time from pairing to birth, interlitter interval, litter size at birth, and litter size at weaning.

Generally, shipping suppressed litter production and delayed its timing, but had less effect on litter size. Overall, 32 of 48 control pairs (67\%) produced 69 litters compared with 37 litters from 21 of 48 pairs (44\%) after shipping. Pairing-to-first-litter intervals were approximately two oestrous cycles shorter in control animals (39 vs 53 days). Averaged over all litters, litter size was higher in control pairs (4.4 vs 4.0).

With respect to genotype, control agouti deer mice were less productive than nonagouti animals, but they reproduced better than nonagoutis after shipping. In control animals, colourmorphs did not differ with respect to litter production or timing, but agouti pairs had smaller litters (first litter: A: 3.1, a: 4.2) and this difference increased at successive litters (third litter A: 3.9, a: 6.0). After shipping, agouti animals produced more litters (A: 22, a: 15), and did so earlier (pairing to birth: A: 47 days, a: 60 days), as well as more frequently (interlitter interval: A: 32 days, a: 51 days). Litter size was also more similar between genotypes after shipping (A: 4.0, a: 4.1). Overall, control agouti animals produced $37 \%$ fewer offspring than nonagouti pairs ( $\mathrm{A}: 116$ neonates, a: 185 neonates), but after shipping agouti deer mice produced $43 \%$ more offspring than nonagouti animals (A: 87 neonates, a: 61 neonates). In sum, transport stress suppressed reproduction for several weeks after shipping and this suppression was exacerbated in nonagouti deer mice.

Keywords Peromyscus maniculatus; deer mice; transport stress; agouti

Although small rodents are frequently transported across long distances by non-natural methods, the effects of transport are not well quantified especially in the longer term.

Acute effects, such as weight loss, tail

Present address: Department of Biology, Smith College, Northampton, MA 01063, USA lesions, and altered immune function (Wallace 1976, Koopman et al. 1984, Aguila et al. 1988) are known and may exhibit genetic differences (Wallace 1976), but more chronic effects, such as those on the timing and frequency of reproduction after shipping, have not been studied. 
In conjunction with establishing colonies of two allelomorphs (agouti and nonagouti) of deer mice (Peromyscus maniculatus) in the UK, effects of transatlantic shipment on reproduction were assessed in deer mice which had been maintained as separate genetic lineages at the agouti coat-colour locus for at least $\mathbf{2 0}$ generations (Horner et al. 1980).

Over $70 \%$ of $130-140$ inbred mouse strains and over $80 \%$ of 50 inbred rat strains which have been characterized at the agouti locus are homozygous for the nonagouti allele. These include several of the most widely used mouse strains, e.g. AKR, DBA, and C57BL mice (Staats 1981, Festing 1989) as well as Long Evans rats (Festing 1979). If agouti and nonagouti deer mice differ in their response to transport, then more common laboratory rodents which differ at that locus may do so as well. The biochemistry and physiology of the product of the agouti locus (agouti protein) suggests that reproductive differences in response to stress might occur between the two allelomorphs.

Nonagouti is a recessive allele of the agouti locus found in many species (Searle 1968). A mutation at the start codon prevents synthesis of agouti protein (Hustad et al. 1995). Dominant agouti alleles (e.g. lethal yellow) may be associated with excess agouti protein (Miller et al. 1993), whereas the recessive nonagouti allele is associated with deficient or non-existent agouti protein (Hustad et al. 1995). In effect, nonagouti may be a naturally produced 'knock-out' of the agouti locus, at least in M us. The most obvious phenotypic effect of lack of agouti protein is solid black pelage in nonagouti animals. However, agouti and nonagouti deer mice also differ in regional levels of neural catecholamines (Hayssen et al. 1994) as well as in their behavioural profiles (Hayssen 1997).

Physiologically, agouti protein is a paracrine regulator of melanocyte-stimulating hormone (MSH), an opiomelanocortin with effects on sexual behaviour (Hughes et al. 1988, Wilson et al. 1991) and suckling (Hill et al. 1991) in addition to its regulation of coat colour. At the molecular level, agouti protein antagonizes $\mathrm{MSH}$ at melanocortin receptors on pigment cells and in neural tissues ( $\mathrm{Lu}$ et al. 1994). Extrapigmental antagonism of MSH by agouti protein may cause some of the pleiotropic effects of the agouti locus. However, some actions of agouti protein may be independent of MSH (Hunt \& Thody 1995).

Suppression of reproductive function is a well-known correlate of stress (Johnson et al. 1992, Moberg 1991). The exact mechanism for this interaction is not precisely understood, but may be influenced by opiomelanocortins via corticotrophin-releasing factor (Johnson et al. 1992, Moberg 1991). A drenocorticotrophic hormone (ACTH) is the opiomelanocortin usually associated with inhibition of reproduction after stress, but evidence for the central role of this hormone is lacking for deer mice. For instance, reproduction is suppressed in high density populations of deer mice, but adrenal histology of inhibited animals suggests that ACTH alone does not account for the reproductive suppression (Coppes \& Bradley 1984). In addition, exposing recently inseminated females to the odour of strange males blocks implantation in deer mice, but, although ACTH is released and corticosteroid levels elevated, neither appears to cause the pregnancy block (Bronson et al. 1969).

Melanocyte-stimulating hormone rather than ACTH may influence the stress response in deer mice. Hypothalamic corticotropin releasing factor from the hypothalamus may release $\mathrm{MSH}$ from pituitary melanotrophs (A utelitano et al. 1990) as well as ACTH from pituitary corticotrophs. Although MSH is identical to the first 13 amino acids of ACTH (O'Donohue \& Dorsa 1982), the hormones do not cross-react at their primary receptors ( $\mathrm{MCl}$ for $\mathrm{MSH}$ on pigment cells, MC2 for ACTH in the adrenal cortex, Mountjoy et al. 1992). However, MSH and ACTH exhibit varying degrees of cross-reactivity at neural melanocortin receptors (Tatro 1990, Tatro \& Entwistle 1994). In addition, melanocortins have been identified in a variety of reproductive tissues including gonads and placentae (Bardin et al. 1987). Therefore, paracrine regulation of melanocortins by agouti protein to alter reproduction is possible either via neuronal pathways or directly at target 
tissues. In either event, suppression of reproduction in response to stress may differ in agouti and nonagouti animals.

Thus, this study has two objectives. First to quantify the effects of transatlantic shipping on reproduction in deer mice and secondly to assess the effect of the agouti locus on suppression of reproduction due to stress.

\section{Materials and methods}

\section{Animals}

The animals were 192 sexually mature, deer mice (Peromyscus maniculatus gracilis) from colonies established in the mid 1970s from wild stock which included heterozygotes for the nonagouti allele (Horner et al. 1980).

After isolation of individuals homozygous for each allele, the two lines have been maintained as separate allelomorphs. Therefore, the source and captive rearing conditions have been the same for both allelomorphs for at least 20 generations.

Most (97\%) of the 15-40 g deer mice were 2-25 months old, but 6 agouti animals were 46-52 months old. Unlike laboratory mice, Peromyscus are long-lived and maintain reproductive function (Peluso et al. 1980, Steger et al. 1980). In fact, Peromyscus have reproduced in captivity at 66 months old (Burger \& Gochfeld 1992) and the two oldest animals both produced litters in the present experiment. Before the experiment, previous breeders were caged alone and non-breeders were housed in same-sex, sib groups. Most adult deer mice weigh $15-25 \mathrm{~g}$, but some nonagouti animals become obese and can weigh up to $40 \mathrm{~g}$. Deer mice were matched for weight, age, parentage, and parity in each replicate with older animals shipped in February and only 2-5-month-old animals shipped in June.

Common reproductive parameters for deer mice are: first oestrus: 49 days; oestrous cycle length: 4-6 days; gestation length: 21-23 days (25-27 days with suckling); lactation: 21-23 days; interlitter interval: 27-35 days; litter size: 4-5 young, range 1-9 (Hayssen et al. 1993). In principle, four litters could have been produced in the 110-day experimental period, however, in practice, no pair produced more than three litters.

\section{Animal quarters}

In the USA, animals were housed in a secure, purpose-built, animal facility. In England, animals were housed in purpose-built, quarantine rooms within a secure, animal facility. All animals were on a 14-h artificial light : 10-h dark photoperiod. In England, temperature was $20^{\circ} \mathrm{C} \pm 1^{\circ} \mathrm{C}$; relative humidity was $50 \% \pm 10 \%$; and ventilation was from fresh air at 15-20 changes/ hour. In the USA, temperature was $21^{\circ} \mathrm{C} \pm 1{ }^{\circ} \mathrm{C}$; relative humidity was $50 \% \pm 10 \%$; and ventilation was 20 changes/ hour.

\section{Caging}

In the first replicate, caging in England was approximately half the volume of caging in the USA. In addition, the solid walls and floors did not provide opportunity for climbing. In the second replicate, cages were also shipped to England and were identical to those in the USA. Specifically, in England opaque-plastic mouse-cages (12 cm high, $25 \mathrm{~cm}$ wide, $41 \mathrm{~cm}$ long) with stainless-steel wirelids were used for first replicate with dustfree, washed, wood shavings (Betabed, Datesand Ltd, from Wm Lillico \& Son, Wonham Mill, Betchworth, Surrey RH3 7AD). For all other groups, custom-built cages with stainless-steel wire-mesh on all sides except the back $(30 \mathrm{~cm}$ high, $40 \mathrm{~cm}$ wide, $30 \mathrm{~cm}$ long) were hung above paperlined stainless-steel trays to collect droppings. Cages were cleaned every 2-4 weeks. Glass nesting jars (various sizes), cardboard tubes, and paper bedding-material (in UK: shredded paper wool from Wm Lillico \& Son, Wonham Mill, Betchworth, Surrey RH3 7AD; in USA: Kim Wipes, Kimberly-Clark Corporation, Roswell, GA 30076-2199) were also provided.

\section{Diet and feeding}

The diet, modified from Dice (1929) and available ad libitum, was a mixture approximately $3: 2: 1: 1$ (by weight) of rolled oats (Quaker Oats Company, PO Box 049002, Chicago, IL 60604-9003), wild-bird seed (43\% 
cracked corn, $40 \%$ white millet, $10 \%$ black oil sunflower-seeds, $5 \%$ striped sunflowerseeds, 2\% peanut hearts), wheat germ (Quaker Oats Company, PO Box 049003, Chicago, IL 60604-9003), and rodent lab chow. In England, rodent chow was B \& K Universal's rat and mouse standard diet (The Field Station, Grimston Aldbrough Hull, N Humberside HU11 4QE). In the USA, rodent chow was Harlan Teklad rodent diet (W) 8604 (PO Box 44220, Madison, WI 53744-4220). 'Treats', usually fruit or vegetables (equivalent in size to one-eighth of an apple per adult), were provided twice each week. Diverse local sources were used for dietary additives. Untreated tap water was available ad libitum for all animals.

\section{Experimental design}

The experimental design essentially conforms to a replicated two-way analysis of variance with stress and genotype as independent variables and a variety of reproductive measures as dependent variables. Sample-size per cell was 24 pairs of deer mice with 12 pairs per cell in each replicate. The replicate effect was treated as an independent variable to account for differences in the February and June shippings including the caging difference. Husbandry, diet, and environment were as similar as possible in control and experimental groups, but the unavoidable differences described above cannot be completely excluded from the potential stress effect.

\section{Shipping}

Overnight, transatlantic air-shipment in February and in June provided an acute stress for experimental animals. A pproximately, $12 \mathrm{~h}$ before shipping, each experimental mouse was placed individually into smallmammal Sherman traps (HB Sherman Traps Inc, Tallahassee, FL 32316) with fresh fruit and potato (as a source of water), small amounts of bedding, and dry food (rodent chow and seeds). Commercially available transport-containers made of treated cardboard and wire mesh were not used because a preliminary trial indicated that deer mice could chew their way out within $12 \mathrm{~h}$. Traps (with animals inside) were returned to each animal's home cage to await crating.

In early morning, traps were packed into one of two wooden shipping crates ( $51 \mathrm{~cm} \times 56 \mathrm{~cm} \times 17 \mathrm{~cm}$ ), lined with styrofoam to dampen noise, and provided with $2.5 \mathrm{~cm}$ vent holes for air. Hardware cloth ( $1 \mathrm{~cm}$ wire mesh) was fitted between traps which permitted air flow but kept traps from moving. The crates had been used successfully a decade earlier to transfer A ntechinus (a dasyurid marsupial) from Australia to the USA (Dickman et al. 1987). Each shipping crate contained equal numbers of each sex and allelomorph for a total of 24 deer mice in 4 layers of 6 animals with a single sex and morph per layer.

After crating, mice sat for $1-3 \mathrm{~h}$ before automobile or truck transport 110 miles to the shipping agent with subsequent transportation to the air carrier. In the second (June) replicate, the air carrier refused the shipment an hour before scheduled departure and the animals were moved to a second carrier for transatlantic travel. After landing and customs clearance, animals travelled an additional 150 miles in a Home Office approved, quarantine-vehicle. Time confined in shipping crates was $27 \mathrm{~h}$ (first shipment) or $36 \mathrm{~h}$ (second 'bumped' shipment). This time does not include the overnight spent in a trap before crating. Pairing of the mice took place immediately after uncrating. Pairing in control deer mice took place while experimental animals were in transit.

\section{Mortality}

No animals were lost during the relatively uneventful first shipment, however, 8 of 48 animals died during, or immediately after, the second ('bumped') shipment. Two control animals died 5 days after pairing during the second replicate. No other mortality occurred in the second replicate. In the first replicate, five animals died before the end of the experiment: four control animals (32, 83, 86, and 86 days after pairing) and one experimental animal (16 days postpairing). No post-mortem analyses were conducted. 
Reproductive measures

Space limitations in the USA colony forced removal of males 86 days after pairing in the first replicate. With a gestation length of 2123 days, the maximum pairing to birth interval would be 107-109 days. In fact, none of the 96 pairs produced a litter 108 to 114 days after pairing. Thus, reproductive parameters were analysed for the first 110 days after pairing for all groups.

Temporal and energetic components of reproduction were monitored in shipped and control pairs by daily inspection. Timing of reproduction was assessed by two measures: (a) pairing to birth: number of days between pairing and birth of the first litter and (b) interbirth interval: number of days between birth of first and second litters or second and third litters. To prevent further stress, litters were not weighed, however, energetic components of reproduction were estimated by three measures: (a) fecundity: proportion of pairs which produced a litter within 110 days of pairing, (b) litter size at birth: number of young (including stillborns) observed within $24 \mathrm{~h}$ of birth, and (c) litter size at weaning: number of young present 21 days after birth. Young were separated from their parents at 21 days.

\section{Statistical analysis}

Chi-square tests (Sokal \& Rohlf 1981) were used on fecundity data with replicates and allelomorphs combined. For other dependent variables, analysis of variance with genotype (agouti vs nonagouti), shipping (control vs shipped), and replicate (February vs June) as independent variables were used to test for interaction effects. Simpler regression models were subsequently calculated eliminating non-significant effects. Sample sizes were too small for multivariate analysis of variance, as only 16 of 96 pairs produced three litters. Parametric analyses were done using Systat ${ }^{\mathrm{TM}}$ version 4 (Systat Inc, Evanston, IL, USA).

\section{Legislative compliance}

Animal care and handling followed legislated standards of both countries (UK: A nimals (Scientific Procedures) Act 1986, US: Guide for the Care and Use of Laboratory A nimals,
National Institutes of Health, 1985). Shipping was in accordance with international regulations for humane transport. In England, deer mice were housed in Home Office approved and inspected quarantine rooms on site at the University of Nottingham.

\section{Results}

Both transatlantic shipping and genotype had significant effects on reproduction in deer mice but the replicate (February vs June) effect did not. Overall, shipping delayed reproduction and the effect was stronger in nonagouti pairs. The shipping-by-genotype interaction effect was apparent across litters over time rather than for single dependent variables. In control animals, genotype differences were also apparent as nonagouti pairs had larger litter sizes. These results are detailed first for the effects of shipping and then for genotype effects. The stronger response of nonagouti deer mice to shipping is described under genotype effects.

\section{Effects of transatlantic shipping}

Reproductive performance was suppressed after shipping. Not only did fewer pairs produce litters after shipping but only four pairs produced the maximum three litters. Overall 32 control pairs produced offspring compared with 21 experimental pairs. Considering only pairs which survived, $70 \%$ of 46 control pairs produced litters within 110 days compared with $50 \%$ of 42 pairs of deer mice which were shipped $\left(x^{2}=3.9, P<0.05\right)$. Similar numbers of control and shipped pairs produced only one litter, but only 12 control and four shipped pairs produced the maximum number of litters. Most control pairs produced two or three litters, but most shipped pairs produced only one or two.

Not only did a smaller proportion of shipped deer mice reproduce, but they did so significantly later than control animals (Table 1; $F=5.50 ;$ df 1,51; $P=0.023$ ). Replicate and interaction effects were not significant. The interval between pairing and birth was approximately two oestrous cycles longer in shipped animals (control: 39.4 days vs shipped: 53.5 days). In addition, the interval between the first and second litters was 
Table 1 Mean pairing to birth and interlitter intervals (days) for control and shipped deer mice which differ at the agouti locus. Replicates combined. Number of litters in parentheses

\begin{tabular}{|c|c|c|c|c|}
\hline \multirow[b]{2}{*}{ Treatment } & \multirow[b]{2}{*}{ Colour } & \multirow[b]{2}{*}{ Pairing to birth } & \multicolumn{2}{|c|}{ Interlitter interval } \\
\hline & & & First to second & Second to third \\
\hline \multirow[t]{2}{*}{ Control } & Agouti & $38.9^{a}(15)$ & $30.8^{\mathrm{c}}(11)$ & $28.7^{e}(7)$ \\
\hline & Nonagouti & $39.9^{\mathrm{a}}(17)$ & $34.4^{c}(14)$ & $33.0^{e} \quad(5)$ \\
\hline \multirow[t]{2}{*}{ Shipped } & Agouti & $46.7^{\mathrm{a}, \mathrm{b}} \quad(10)$ & $32.4^{c}(8)$ & $30.8^{\mathrm{e}}(4)$ \\
\hline & Nonagouti & $59.6^{\mathrm{b}}(11)$ & $51.5^{\mathrm{d}}(4)$ & $--(0)$ \\
\hline Pooled SD & & $22.02(53)$ & $11.20(37)$ & $6.12(16)$ \\
\hline
\end{tabular}

Means with the same superscript have overlapping $95 \%$ confidence intervals

approximately one oestrous cycle longer in shipped animals (control: 32.8 days vs shipped: 38.8 days) but this was primarily due to long intervals in shipped nonagouti animals (shipping-by-genotype interaction, $F=17.254 ;$ df 1,34; $P<0.0005$ ). By the third litter, interlitter intervals were nearly identical (control: 30.5 days vs shipped: 30.8 days). The shortening of reproductive intervals over time was primarily because pairs with long pairing-to-birth intervals did not have time for subsequent litters within the experimental period.

Reproductive output was also lower after shipping. Overall, 449 young from 106 litters were born of which 385 survived until weaning. Two-thirds of this reproductive output was from control pairs. Litter size at birth from control pairs (4.36) was slightly higher than that from shipped pairs (4.00), but, after removing the effects of genotype, the difference was not significant ( $\mathrm{F}=0.51$; df 1,45; $P=0.48$ ). Litter size at birth increased from the first to third litters in both control and experimental agouti animals as well as in control nonagoutis but decreased in shipped nonagouti deer mice. This led to a significant shipping-by-genotype effect for the second litter ( $\mathrm{F}=5.19 ;$ df 1,$29 ; \mathrm{P}=0.03)$. Replicate and all other interaction effects were not significant.

Litter sizes at weaning were not significantly different in control and shipped animals (control: 3.62 , shipped: 3.61 ), although overall survival to weaning was higher in England (UK: 91\%, USA: 83\%).

\section{Genotype effects}

Both agouti and nonagouti deer mice reacted to shipping by delaying reproduction, however, nonagouti animals did so to a greater extent (Table 1). A mong control deer mice, the number of litters born was similar between allelomorphs ( $\mathrm{A}: 33$ litters, a: 36 litters). Slightly fewer agouti pairs produced litters (A: 15, a: 17), but more of them produced the maximum of three (A: 7, a: 4). Among shipped deer mice, nonagoutis produced fewer litters (A: 22, a: 15) and no

Table 2 Mean litter sizes at birth and weaning for three sequential litters produced within 110 days after pairing from control and shipped deer mice which differ at the agouti locus. Replicates combined. Sample sizes as in Table 1

\begin{tabular}{|c|c|c|c|c|c|c|c|}
\hline \multirow[b]{3}{*}{ Treatment } & \multirow[b]{3}{*}{ Colour } & \multicolumn{6}{|c|}{ Litter size } \\
\hline & & \multicolumn{2}{|l|}{ First } & \multicolumn{2}{|c|}{ Second } & \multicolumn{2}{|l|}{ Third } \\
\hline & & Birth & Weaning & Birth & Weaning & Birth & Weaning \\
\hline \multirow[t]{2}{*}{ Control } & Agouti & $3.1^{\mathrm{a}}$ & $2.5^{\mathrm{c}}$ & $3.8^{d}$ & $3.6^{\dagger}$ & $3.9^{9}$ & $3.6^{\mathrm{h}}$ \\
\hline & Nonagouti & $4.2^{b}$ & $3.2^{c}$ & $5.9^{e}$ & $4.6^{f}$ & $6.0^{g}$ & $5.6^{\mathrm{h}}$ \\
\hline \multirow[t]{2}{*}{ Shipped } & Agouti & $3.7^{a, b}$ & $3.1^{\mathrm{c}}$ & $4.1^{d}$ & $4.1^{f}$ & $4.2^{g}$ & $4.0^{\mathrm{h}}$ \\
\hline & Nonagouti & $4.2^{b}$ & $3.6^{c}$ & $3.8^{d}$ & $3.8^{f}$ & -- & -- \\
\hline Pooled SD & & 1.74 & 2.18 & 1.72 & 2.05 & 1.93 & 1.96 \\
\hline
\end{tabular}

Means with the same superscript have overlapping $95 \%$ confidence intervals 
nonagouti pair produced three litters, although $40 \%$ of agouti pairs did so. In addition, interlitter intervals were longer for nonagouti pairs after shipping (shipping-bygenotype interaction, $\mathrm{F}=7.254$; df 1,34; $\mathrm{P} \varangle 0.0005)$. Thus, agouti deer mice produced second litters more quickly.

Litter size differed between allelomorphs in two ways (Table 2). First in control animals, nonagoutis had larger litter sizes (Litter 1: $\mathrm{F}=3.31$; df 1,51; $\mathrm{P}=0.075$; Litter 2: $F=15.231$; df 1,34; $P<0.0005$; Litter 3: insufficient data). Second, after shipping litter size was depressed for nonagoutis but not for agouti pairs (Litter 2: $F=5.19 ;$ df 1,29; $P=0.03$ ). Maximum, as well as average, litter size was larger for nonagoutis (A: range 1-6 neonates, a: range 1-9 neonates). Only one-third of litters from all agouti pairs had five or more young compared with two-thirds of litters from control nonagouti pairs. Experimental nonagouti litters ranged from 1-7 with 47\% having five or more young. Thus in total, control agouti pairs produced fewer offspring than nonagoutis (A: 116 neonates, a: 185 neonates), but after shipping, agouti pairs produced more (A: 87 neonates, a: 61 neonates). Litter size at weaning did not exhibit genotype effects, although overall survival for nonagouti litters was $82 \%$ compared with $90 \%$ survival in agouti litters.

\section{Replicate effects}

The two replicates of the experiment were different in several ways. First, caging used in England for the first replicate was smaller and had solid floors. Second, the first replicate occurred during winter (February) whereas the second occurred in early summer (June). Finally, the second shipment took longer and resulted in several deaths. Despite these differences, replicate effects had no significant effect on the assessed reproductive profile.

\section{Discussion}

Two aspects of the experimental profile need mention before discussing the main results. First, the June 'bumped' shipment was clearly more stressful as $17 \%$ of the animals died. Unexpectedly, the reproductive profiles of animals which survived are not significantly different between the two replicates suggesting the additional stress had no effect on reproduction. However, if the animals which died were those most sensitive to stress, then their deaths effectively removed the most sensitive animals from the experiment. Thus, although stress was greater in the second shipping, the assessed profiles came from animals which could cope with that stress. The mortality may have biased the second shipment in favour of animals less apt to show stress effects.

Second, although housing, diet, and ambient environments in the USA and England were matched to the extent possible, they were not identical. Therefore, differences observed between shipped and control animals as well as shipping-by-genotype interaction effects may be due to environmental differences between facilities at Smith College and University of Nottingham (such as slight differences in rodent chow or treats, air pressure and quality, magnetic field, ambient odours, etc) rather than the stress of shipping. The fact that deer mice from widely different habitats and captive animals from different colonies have similar reproductive profiles (Hayssen et al. 1993) suggests that environmental effects may have been slight compared with shipping stress. However, they cannot be discounted. In fact, habituating to slight differences in a new environment may be one aspect of transit stress.

Regardless of exact cause, reproductive performance was suppressed in deer mice after transatlantic air flight and the effect was stronger for nonagouti animals. Across sequential litters, this genotype-by-shipping interaction effect is apparent in the proportion of animals reproducing as well as in litter size and interlitter intervals.

For the main effect of shipping, not only was the proportion of pairs which produced litters significantly lower for shipped animals, but experimental animals delayed reproduction by at least two oestrous cycles and a smaller proportion produced more than one litter. Thus, both timing and frequency of reproduction were delayed after shipping.

For agouti deer mice, litter size was not altered by shipping. This result complements 
data for primates, guineapigs, and rabbits. For various primates, jet transport of pregnant females did not decrease the number of viable offspring (Sackett 1981). For pregnant guineapigs (Cavia) (Bailey et al. 1986) and rabbits (O ryctolagus) (Stephens $\&$ A dams 1982), simulated transport (vibration stress and sound) had no effect on a variety of reproductive parameters including gestation length, litter size, and perinatal mortality. Thus, for both large and small mammals, one outcome of pregnancy, litter size, is not altered by shipping.

The reproductive profiles of agouti and nonagouti deer mice differed significantly after transatlantic shipment. Reproduction after shipping was suppressed to a greater extent in nonagouti deer mice than in agouti pairs. N ot only did fewer nonagouti pairs produce multiple litters, but also, pairing-tobirth and interlitter intervals were longer, and litter sizes were smaller, compared with control nonagouti deer mice. The shorter interlitter intervals for agouti pairs suggest that they may have recovered from shipping or adjusted to the new environment more quickly. Thus, lack of agouti protein appears to exacerbate effects of shipping.

A genotype effect was apparent not only in the reduced reproductive output of nonagouti pairs after shipping but also in the larger litter size of control nonagouti pairs. These data also provide evidence of possible differences in fertility associated with the agouti locus.

Thus, the nonagouti allele may be associated with higher ovulation rates or lower uterine mortality. A complementary result occurs in Icelandic sheep and is associated with a dominant mutation of the agouti locus $\left(A^{\mathrm{wh}}\right)$. The coat-colour effect of $A^{\text {wh }}$ is opposite to that of the recessive nonagouti allele, that is, $A^{\text {wh }}$ completely suppresses black pigment. The effect of $A^{\text {wh }}$ on fertility is also opposite to that of the nonagouti, that is, $A^{\text {wh }}$ is associated with depressed fertility (Adalsteinsson 1975). Thus, overproduction of agouti protein is associated with smaller litter size in sheep and underproduction of agouti is correlated with larger litter size in deer mice. These limited data suggest a role for agouti and/ or melanocortins either in ovulation rate or with respect to prenatal mortality.
Additionally in Icelandic sheep, the $A^{\text {wh }}$ allele is associated with fewer out-of-season lambings whereas the nonagouti allele in these sheep is associated with more out-ofseason lambings (Dyrmundsson \& Adalsteinsson 1980). Thus, in sheep, timing of reproduction relative to environmental cues may be affected by the agouti locus. Similarly, in deer mice, timing of reproduction relative to transatlantic air travel was affected by the agouti locus. Thus, agouti may havea role in triggering reproduction relative to external cues.

How agouti may influence reproduction is not clarified by these data. Paracrine regulation of melanocortins by agouti protein to alter reproduction is possible via neuronal pathways or directly at target tissues. In addition, behavioural differences between agouti and nonagouti animals (Hayssen, in press) may indirectly influence reproductive capacity. For example, nonagouti animals bite and attack less often than agouti deer mice in a handling situation. If they are also less aggressive in male/ female encounters, mating may be less stressful overall and ovulation rate correspondingly higher.

In conclusion, these data have two potential ramifications. First, they indicate that transport stress may have different effects on reproduction in strains which differ at the agouti locus. Thus, comparative studies which do not take this into consideration may be suspect if they are conducted within the first few weeks of arrival. Second, Bronson (1989, p. 232) suggested that comparison of closely related lines that differ only in one control mechanism could improve our understanding of reproductive biology. Nonagouti animals lack an important paracrine regulator of melanocortins and nonagouti deer mice exhibited a different reproductive profile after transatlantic shipping. Comparisons of agouti and nonagouti deer mice may improve our understanding of reproductive biology by allowing assessment of the regulation mammalian reproduction by melanocortins.

Acknowledgments Dr B. E. Horner graciously supervised data collection and colony maintenance in the United States. M. Baker and L. Gold monitored 
and cared for deer mice in the United Kingdom. D. Ewell and V. Flood cared for animals in the United States. Technical assistance by $M$. Soja and M. McCusker is gratefully acknowledged.

Research support was provided by the Blakeslee Fund to Smith College and by the University of Nottingham.

\section{References}

Adalsteinsson S (1975) Depressed fertility in Icelandic sheep caused by a single colour gene. Annales de Genetique de la Selection Animale 7, 445-7

Aguila HN, Pakes SP, Lai WC, Lu Y-S (1988) The effect of transportation stress on splenic natural killer cell activity in C57BL/6] mice. Laboratory Animal Science 38, 148-51

Autelitano DJ, Blum M, Lopingco $M$, Allen RG, Roberts JL (1990) Corticotropin-releasing factor differentially regulates anterior and intermediate pituitary lobe proopiomelanocortin gene transcription, nuclear precursor RNA and mature mRNA in vivo. N euroendocrinology 15, 123-30

Bailey KJ, Stephens DB, Delaney CE (1986) Observations on the effects of vibration and noise on plasma ACTH and zinc levels, pregnancy and respiration rate in the guineapig. Laboratory A nimals 20, 101-8

Bardin CW, Chen CLC, Morris PL, et al. (1987) Proopiomelanocortin-derived peptides in testis, ovary, and tissues of reproduction. Recent Progress in $\mathrm{H}$ ormone Research 43, 1-28

Bronson FH, Eleftheriou BE, Dezell HE (1969) Strange male pregnancy block in deer mice: prolactin and adrenocortical hormones. Biology of Reproduction 1, 302-6

Bronson FH (1989) M ammalian Reproductive Biology. Chicago: University of Chicago Press

Burger J, Gochfeld M (1992) Survival and reproduction in Peromyscus leucopus in the laboratory: viable model for aging studies. Growth 56, 17-22

Coppes JC, Bradley EL (1984) Serum ACTH and adrenal histology in reproductively inhibited male prairie deer mice (Peromyscus maniculatus bairdi). Comparative Biochemistry and Physiology 78A, 297-306

Dice LR (1929) A new laboratory cage for small mammals, with notes on methods of rearing Peromyscus. Journal of $M$ ammalogy 10, 116-24

Dickman CR, Hayssen V, King DH (1987) Effects of seasonal reversal of photoperiod on the reproductive rhythm of a small marsupial. Journal of Zoology 213, 766-8

Dyrmundsson OR, Adalsteinsson S (1980) Coat-color gene suppresses sexual activity in Icelandic sheep. Journal of Heredity 71, 363-4

Festing MFW (1979) Inbred strains. In: The Laboratory Rat. Volume 1: Biology and Diseases (Baker HJ, Lindsey JR, Weisbroth SH, eds). New York: Academic Press, pp 55-72
Festing MFW (1989) Inbred strains of mice. In: Generic Variants and Strains of the Laboratory M ouse, 2nd edn. (Lyon MF, Searle AG, eds). New York: Oxford University Press, pp 636-48

Hayssen V (1997) Effects of the nonagouti coat-color allele on behavior of deer mice (Peromyscus maniculatus): a comparison with Norway rats (Rattus norvegicus). Journal of Comparative Psychology 111, 419-23

Hayssen V, Gunawardhana S, Meyer J (1994) The agouti coat-color locus may influence brain catecholamines: regional differences in norepinephrine and dopamine in the brains of two color-morphs of deer mice (Peromyscus maniculatus). Comparative Biochemistry and Physiology 107C, 51-5

Hayssen V, van Tienhoven A, van Tienhoven A (1993) Asdell's Patterns of Mammalian Reproduction: A Compendium of Species-Specific Data. Ithaca, NY: Cornell University Press

Hill JB, Naby GM, Frawley LS (1991) Suckling unmasks the stimulatory effect of dopamine on prolactin release: possible role for a-melanocyte stimulating hormone as a mammotrope responsiveness factor. Endocrinology 129, 843-7

Horner BE, Potter GL, Van Ooteghem S (1980) A new black coat-color mutation in Peromyscus. Journal of Heredity 71, 49-51

Hughes AM, Everitt BJ, Herbert J (1988) The effects of simultaneous or separate infusions of some proopiomelanocortin-derived peptides (-endorphin, melanocyte stimulating hormone, and corticotrophin-like intermediate polypeptide) and their acetylated derivatives upon sexual and ingestive behaviour of male rats. $\mathrm{N}$ euroscience $\mathbf{2 7}, \mathbf{6 8 9 - 9 8}$

Hunt G, Thody AJ (1995) Agouti protein can act independently of melanocyte-stimulating hormone to inhibit melanogenesis. Journal of Endocrinology 147, R1-4

Hustad CM, Perry WL, Siracusa LD, et al. (1995) Molecular genetic characterization of six recessive viable alleles of the mouse agouti locus. Genetics 140, 255-65

Johnson EO, Kamilaris TC, Chrousos GP, Gold PW (1992) Mechanisms of stress: a dynamic overview of hormonal and behavioral homeostasis. N euroscience and Biobehavioral Reviews 16, 115-30

Koopman JP, van der Logt JTM, Mullink JWMA, et al. (1984) Tail lesions in $\mathrm{C}_{3} \mathrm{H} / \mathrm{He}$ mice. Laboratory A nimals 18, 106-9

Lu D, Willard D, Patel IR, et al. (1994) Agouti protein is an antagonist of the melanocyte-stimulating hormone receptor. $N$ ature 371, 799-802

Miller MW, Duhl DMJ, Vrieling $\mathrm{H}$, et al. (1993) Cloning of the mouse agouti gene predicts a secreted protein ubiquitously expressed in mice carrying the lethal yellow mutation. Genes and Development 7, 454-67 
Moberg GP (1991) How behavioral stress disrupts the endocrine control of reproduction in domestic animals. Journal of Dairy Science 74, 304-11

Mountjoy KG, Robbins LS, Mortrud MT, Cone RD (1992) The cloning of a family of genes that encode the melanocortin receptors. Science 257, 1248-51

O'Donohue TL, Dorsa DM (1982) The opiomelanotropinergic neuronal and endocrine systems. Peptides 3, 353-95

Peluso JJ, Montgomery MK, Steger RW, Meties J, Sacher G (1980) A ging and ovarian function in the white-footed mouse (Peromyscus leucopus) with specific reference to the development of preovulatory follicles. Experimental Aging Research 6, $317-28$

Sackett GP (1981) Pregnancy outcome following jet transport stress in nonhuman primates. Journal of Medical Primatology 10, 149-54

Searle AG (1968) Comparative Genetics of Coat Colour in Mammals. London: Logos Press

Sokal RR, Rohlf FJ (1981) Biometry, 2nd edn. San Francisco: Freeman \& Co

Staats J (1981) List of inbred strains. In: Genetic Variants and Strains of the Laboratory Mouse (Green MC, ed). New York: Gustav Fischer Verlag, pp 373-6
Steger RW, Peluso JJ, Huang HH, et al. (1980) Effects of advancing age on the hypothalamic-pituitaryovarian axis of the female white-footed mouse (Peromyscus leucopus). Experimental Aging Research 6, 329-40

Stephens DB, Adams CE (1982) Observations on the effects of vibration stress and sound on pregnancy, parturition and respiration in the rabbit. Laboratory A nimals 16, 341-7

Tatro JB (1990) Melanotropin receptors in the brain are differentially distributed and recognize both corticotropin and a-melanocyte stimulating hormone. Brain Research 536, 124-32

Tatro JB, Entwistle ML (1994) Heterogeneity of brain melanocortin receptors suggested by differential ligand binding in situ. Brain Research 635, 148-58

Wallace ME (1976) Effects of stress due to deprivation and transport in different genotypes of house mouse. Laboratory A nimals 10, 335-47

Wilson CA, Thody AJ, Hole DR, Grierson JP, Celis ME (1991) Interaction of estradiol, a-melanocytestimulating hormone, and dopamine in the regulation of sexual receptivity in the female rat. $\mathrm{N}$ euroen docrinology 54, $14-22$ 